\title{
Efektifitas Kompres Ekstrak Jahe Terhadap Nyeri Sendi Lansia Dengan Arthritis Gout Di Panti Sosial Tresna Werda Khusnul Khotimah Pekanbaru Riau
}

\author{
Silvia Nora Anggreini ${ }^{1)}$, ${ }^{2)}$ Awaliyah Ulfah Ayudytha \\ ${ }^{1}$ Program Studi Ilmu Keperawatan, STIKes Pekanbaru Medical Center, Jl. Sisingamangaraja no \\ 99 Email : vissdeus@gmail.com \\ ${ }^{2}$ Program Studi Ilmu Keperawatan, STIKes Pekanbaru Medical Center, Jl. Lembaga \\ Pemasyarakatan no 25 Email : dhita87@yahoo.com
}

\begin{abstract}
Compress Ginger Extract is non pharmacological treatment to lower joint pain with a variety of good effects such as stimulating an erection, inhibiting the release of enzyme 5-lipooksigenase and cyclooxygenase and increase endocrine gland activity. The number of elderly who experience joint pain in this way is also effective because the compress ginger extract has many benefits one of them meberi sense of warmth in the joints. This study aims to determine the effectiveness of compress ginger extract on the reduction of joint pain in the elderly of panti sosial tresna werdha khusnul khotimah pekanbaru riau. This research type is quantitative with pre experimental design research, Sampling technique by total sampling, the sample of this study amounted to 39 respondents, the intervention is given once for 3 days with 13 respondents every day. Evaluation by filling in the observation sheet. The result of alternative $t$ test of wilcoxon was found the effectiveness of ginger extract compress on the decrease of aged joint pain with mean before ginger extract was given 6.83 with standard deviation 1,298 and after given compress ginger extract was 4,11 with standard deviation 1,410, $p$ value 0,000 was statistically significant $(p<0.05)$. The results of this study can be a consideration of existing nurses in the hospital and in the community in the reduction of joint pain in the elderly.
\end{abstract}

Keywords: Elderly, Ginger Extract Compress, Decreased Joint Pain

References: 22 References (2009-2016)

\section{ABSTRAK}

Gout merupakan penyakit dimana terjadi penumpukan asam urat dalam tubuh secara berlebihan. Gout ditandai dengan (peradangan sendi) yang akut. Sebagian besar dari lansia mengalami gangguan sistem muskuloskletal, yang menyebabkan nyeri sendi. Pengobatan farmakologis tindakan pemberian obat sebagai penurunan nyeri seperti pemberian obat anti inflamasi dan memiliki efek seperti mual, diare, perdarahan tukak, kerusakan pada ginjal, dan gangguan kardiovaskuler. Pengobatan non farmakologis adalah tindakan dalam batas keperawatan yang dapat digunakan untuk menurunkan nyeri sendi pada lansia Adapun Pengobatan non farmakologis seperti mengompres bagian sendi. Jahe adalah obat yang menjadi pilihan utama untuk menurunkan nyeri sendi pada lansia dengan (Artritis Gout) karena selain tidak memiliki efek samping bagi kesehatan, obat ini juga mudah dikonsumsi, mudah terjangkau. Penelitian ini bertujuan untuk mengetahui efektifitas kompres ekstrak jahe terhadap penurunan nyeri sendi pada lansia di panti sosial tresna werdha khusnul khotimah pekanbaru riau. Jenis penelitian ini adsalah kuantitatif dengan desain penelitian pre eksperimental design. Teknik pengambilan sampel dengan cara total sampling, sampel penelitian ini berjumlah 39 responden, intervensi diberikan dalam 1 kali intervensi selama 3 hari dengan 13 responden setiap harinya. Evaluasi dengan cara melihat penurunan nyeri sendi dengan menggunakan skala nyeri. Hasil uji Marginal Homogenelty didapatkan adanya efektifitas kompres ekstrak jahe terhadap penurunan nyeri sendi lanjut usia dengan rata-rata sebelum diberikan kompres ekstrak jahe adalah 6,83 dengan standar deviasi 1,298 dan sesudah diberikan kompres ekstrak jahe adalah 4,11 dengan standar deviasi 1,410, p value 0,000 secara statistik signitifkan $(\mathrm{p}<0,05)$. Hasil penelitian ini dapat menjadi pertimbangan perawat yang ada dirumah sakit maupun di komunitas dalam penurunan nyeri sendi pada lansia.

$\begin{array}{ll}\text { Kata kunci } & \text { : Lanjut Usia, Kompres Ekstrak Jahe, Penurunan Nyeri Sendi } \\ \text { Daftar Bacaan } & : 22 \text { Referensi (2009-2016) }\end{array}$




\section{PENDAHULUAN}

Lanjut usia (lansia) merupakan dimana seseorang telah mencapai usia 65 tahun ke atas. Lansia bukan penyakit namun merupakan tahap lanjut dari suatu proses kehidupan yang ditandai dengan penurunan kemampuan tubuh untuk beradaptasi dengan stress lingkungan. Lanjut usia akan mengalami berbagai perubahan akibat terjadinya penurunan dari semua aspek diantaranya fungsi biologi, psikologis, sosial dan ekonomi. Perubahan ini akan memberikan pengaruh pada seluruh aspek kehidupan, termasuk status kesehatannya (Abdul \& Sandu,2016).

Secara umum, populasi penduduk lansia 60 tahun keatas pada saat ini dinegara-negara dunia diprediksikan akan mengalami peningkatan. dinegara maju misalnya diperkirakan akan mengalami peningkatan jumlah lansia sebesar 32\% pada tahun 2050. Sementara dinegara berkembang, jumlah penduduk usia 60 tahun keatas diperkirakan akan meningkat 20\% antara tahun 2017-2050 dan termasuk negara Indonesia, yang saat ini menempati urutan keempat setelah China, India dan Jepang yang memiliki jumlah lansia terbanyak (Ari \& Liana,2016).

Peningkatan jumlah penduduk lansia tidak terlepas dari peningkatan derajat kesehatan lansia sehingga meningkatkan usia harapan hidup (UHH). Tahun 2004, UHH penduduk Indonesia adalah 66,2 tahun, kemudian meningkat menjadi 69,4 tahun pada tahun 2006 dan tahun 2009, UHH mencapai 70,6 tahun (Ari \& Liana,2016).

Menurut World Health Organisation (WHO, 2014) menyatakan bahwa usia harapan hidup di Indonesia meningkat 72 tahun. Jumlah penduduk lansia di Indonesia pada tahun 2012 mencapai 28 juta jiwa atau sekitan 8\% dari jumlah penduduk Indonesia. Pada tahun 2025 diperkirakan jumlah lansia membengkak menjadi 40 jutaan dan pada tahun 2050 diperkirakan akan melonjak hingga mencapai 71,6 juta jiwa (Badan Pusat Stastistik, 2012).

Setiap lansia akan mengalami sebuah proses yang alami, proses yang dialami yaitu proses menua. Proses menua mengubah seorang dewasa sehat menjadi seorang yang lemah dan rentan terhadap penyakit. Hal ini disebabkan berkurangnya sebagian besar cadangan sistem fisiologis. Menua merupakan proses alami, yang berarti seorang telah melalui tiga tahap kehidupannya, tahap anak, dewasa, dan tua. Secara umum saat proses menua terjadi, akan menimbulkan banyak perubahan pada tubuh lansia baik itu perubahan fisik, perubahan mental ataupun perubahan psikosiosial (Ari \& Liana,2016).

Perubahan yang terjadi pada lansia antara lain seperti lansia mengalami penurunan daya tahan fisik secara terus menerus dan rentan terhadap serangan penyakit yang dapat menyebabkan kematian. Kondisi fisik lansia mengalami penurunan penampilan seperti pada bagian wajah, tangan, dan kulit,penurunan fungsi dalam tubuh seperti sistem saraf, perut, limpa, dan hati, penurunan kemampuanpanca indra seperti penglihatan, pendengaran, penciuman, dan perasa, serta penurunan motorik seperti kekuatan, kecepatan dan perubahan sistem muskuloskeletal(Stastik Penduduk Lanjut Usia Indonesia, 2014)

Pada lansia sistem muskuloskletal akan mengalami beberapa perubahan seperti perubahan pada jaringan penghubung (kolagen dan elastin), berukurangnya kemampuan kartilago untuk bergerasi, kepadatan tulang berkurang, perubahan struktur otot, dan terjadi penurunan elastisitas sendi (Black Joyce M, 2014). Hal ini menyebabkan sebagian besar dari lansia mengalami gangguan sistem muskuloskletal, yang menyebabkan nyeri sendi adalah tanda atau gejala yang mengganggu persendian, nyeri sendi akan menganggu kinerja bagian tubuh. Pada nyeri sendi biasanya akan muncul rasa tidak nyaman untuk disentuh, muncul pembekakan, peradangan, kelakuan, dan pembatasan gerakan. Penyakit-penyakit gangguan sistem muskuloskletal yang menyebabkan nyeri sendi antara lain: osteoritis, ahrtritis gout, ahrtritis rheumatoid, arthritis infeksi (Aniea, 2016 didalam jurnal Syariffatul, 2014)

Prevalensi asam urat di Indonesia menduduki urutan kedua setelah osteoartritis. Prevalensi asam urat pada populasi di USA diperkirakan 13,6/100.000 penduduk, sedangkan diindonesia sendiri diperkirakan 1,613,6/100.000 orang, prevalensi ini meningkat seiring dengan peningkatan umur (Ari \& Liana,2016).

Prevalensi penyakit sendi secara Nasional sebesar 30,3\% dan prevelensi berdasarkan diagnosis tenaga kesehatan adalah 14\% Prevalensi penyakit sendi di Riau sebesar 29\%dan paling tinggi ditemukan dikampar (44,1\%) diikuti Pekanbaru (39,0\%), Indragiri Hilir (9,3\%), Kampar (7,4\%), dan Rokan Hilir (5,5\%) dan Indragiri Hilir (4,7\%) (Riskesdas Provinsi Riau, 2016)

Hasil survey awal penelitian di Panti Sosial Tresna Werdha didapatkan jumlah lanjut usia sebanyak 69 orang dengan riwayat penyakit yang berbeda-beda. Hasil data yang diperoleh dari Klinik Panti Sosial Tresna Werdha didapatkan 39 lansia yang terdiagnosa asam urat dengan keluhan nyeri dibagian sendi. Dengan jumlah 
responden 39 orang lansia peneliti melakukan pemeriksaan penunjang asam uratkembali kepada seluruh lansia yang terdiagnosa asam urat tersebut dan didapatkan 39 orang lansia yang memiliki penyakit asam urat dengan keluhan nyeri sendi.

Lokasi persendian yang terkena terutama sendi-sendi kecil yaitu sendi jari tangan dan jari kaki. Bila kristal urat tertimbun pada jaringan diluar sendi maka akan membentuk atau topus yaitu benjolan bening dibawah kulit yang berisi kristal urat, kristal urat ini juga dapat menyebabkan timbulnya batu asam urat (Handryani,2011).

Pengobatan farmakologis yaitu tindakan pemberian obat sebagai penurunan nyeri. Biasanya dengan pemberian obat-obat analgesik seperti pemberian obat anti inflamasi nonsterois (OAINS), contoh aspirin dan ibuprofen. Penggunaan obat-obat analgesik memiliki dampak buruk seperti rasa tidak nyaman pada saluran pencernaan, mual, diare, perdarahan tukak, dapat juga mengakibatkan kerusakan pada ginjal, dan gangguan kardiovaskuler. Selain analgesik oral biasanya juga dalam nyeri sendi seringkali dengan analgesik topikal seperti balsem. Dalam penggunaan analgesik topical juga memiliki efek samping seperti rasa terbakar atau sengatan untuk sementara pada area yang dioleskan (Syafrifatul, 2014)

Pengobatan non farmakologis yaitu tindakan dalam batas keperawatan yang dapat digunakan untuk nyeri sendi pada lansia (Nurlina, 2010). Selama ini bila terjadi nyeri terutama nyeri sendi, kebanyakan masyarakan dan perawat di Rumah sakit ataupun Puskesmas langsung memberikan tindakan medis (terapi farmakologis) dari pada melakukan tindakan mandiri seperti meberikan kompres jahe dan air hangat, rebusan air daun salam, dan rebusan daun sirsak. Adapun terapi non-farmakologis yang dapat digunakan dalam menurunkan nyeri sendi (Syarifatul, 2014)

Adapun Pengobatan non farmakologis seperti mengompres bagian sendi jaheadalah obat yang menjadi pilihan utama untuk menurunkan nyeri sendi pada lansia dengan (Artritis Gout) karena selain tidak memiliki efek samping bagi kesehatan, obat ini juga mudah dikonsumsi, mudah terjangkau dalam hal segi ekonomi, dan juga tidak berat untuk dikonsumsi (Syafrifatul, 2014). Pengobatan non farmakologis bagi pasien asam urat darah pada dasarnya adalah dengan menjada makanan, mengontrol berat badan, perubahan gaya hidup, olahraga yang cukup, minum air putih secukupnya. Masyarakat menggunakan pengobatan alternatif untuk mengatasi berbagai penyakit (Ari \& Liana, 2016)

Pemberian kompres ekstrakjahe dapat menurunkan nyeri sendi, karena jahe dapat meningkatkan kemampuan kontrol terhadap nyeri, Jahe memiliki rasa pedas dan bersifat hangat. Beberapa bahan dalam jahe diantaranya gingerol, limonene, a-linolenic acid, aspartic, b-sitossterol, tepung kanji, caprilyc acid, capsaicin, chlorogenic acid, dan parsenol. Efek farmakologis yang dimiliki jahe, merangsang ereksi penghambat keluarnya enzim 5-lifooksigenase dan siklooksigenase serta meningkatkan aktivitas kelenjar endokrin (Heryana, 2009). Menurut Puspaningtyas dan Utami 2013, jahe sering kali digunakan sebagai obat nyeri sendi karena kandungan ginerol dan rasa hangat yang ditimbulkannya membuat pembuluh darah terbuka dan memperlancar sirkulasi darah. dan suplai makanan dan oksigen menjadi lebih baik sehingga nyeri sendi akan berkurang (Syafrifatul, 2014)

\section{METODE PENELITIAN}

Jenis penelitian ini adalah penelitian kualitatif dengan desain pre eksperimental design. Pre eksperimental adalah mengungkapkan hubungan sebab-akibat hanya dengan cara melibatkan satu kelompok subjek, sehingga tidak ada kelompok kontrol yang ketat terhadap variable dengan rancangan "one group pretest posttest" (Notoadmojo, 2012). Rancangan ini melibatkan satu kelompok yaitu kelompok kompres Ekstrak jahe.

Populasi dalam penelitian ini berjumlah 39 lansia yang terdiagnosa medis asam urat, memiliki kadar asam urat darah tinggi dan memiliki keluhan nyeri sendi dengan skala nyeri $>3(0-10)$ di panti sosial tresna werdha khusnul khotimah pekanbaru.

Pengambilan sampel berdasarkan distribusi normal dengan total sampling. Teori ini menunjukkan bahwa sampel penelitian disebut dengan sampel besar jika subjek yang diteliti besar dari 39 orang yang akan menghasilkan atau mendekati disribusi normal (Sarwono,2008). Pada penelitian ini yang menjadi sampel adalah 39 orang.

Dalam penelitian ini pengambilan sampel menunjukkan beberapa kriteria Inklusi dan eklusi. Kriteria inklusi adalah kriteria atau ciri-ciri yang perlu dipenuhi oleh setiap anggota populasi yang dapat di ambil sebagai sampel. Sedangkan kriteria eklusi adalah ciri-ciri anggota populasi yang tidak dapat diambil sebagai sampel. Inklusi adalah diantaranya adalah sebagai berikut:

1. Lansia mengalami nyeri sendi dengan skala $>3(0-10)$ 
2. Lansia bersedia menjadi responden

3. Lansia mampu berkomunikasi dengan baik

4. Lansia dengan usia 55-64 tahun

Adapun kriteria eklusi pada penelitian ini diantaranya adalah sebagai berikut:

1. Lansia yang sakit secara fisik sehingga tidak memungkinkan untuk berpatisipasi dalam penelitian ini

Variabel dalam penelitian ini adalah variabel independen dan dependen. Dimana variabel independen adalah efektifitas pemberian kompres ekstrak jahe dan variabel dependen adalah terhadap nyeri sendi pada lansia.

\section{HASIL DAN PEMBAHASAN}

\section{Analisis Univariat}

Tabel 4.1

Distribusi Frekuensi Responden Berdasarkan Karakteristik Umur



Berdasarkan tabel 4.1 didapatkan bahwa responden di penelitian ini yang mayoritas adalah berusia Old yaitu sebanyak 25 orang responden $(69,4 \%)$

Hal ini sejalan dengan teori menurut (Ari \& Liana, 2016) penyebab utama terjadi gout (asam urat) adalah karena adanya deposit/penibulan kristal asam urat dalam sendi. Penimbunan asam urat sendi terjadi pada penyakit dengan metabolisme asam urat abnormal dan kelainan metabolik dalam pembentukan purin dan ekskresi asam urat yang kurang dari ginjal. Beberapa faktor lain yang mendukung seperti: Faktor genetik seperti gangguan metabolisme purin yang menyebabkan asam urat berlebihan (Hiperuricemia), retensi asam urat, atau keduanya. Gangguan metabolisme umumnya berkaitan dengan faktor usia, dimana usia diatas 40 tahun atau perempuan beresiko besar terkena asam urat.

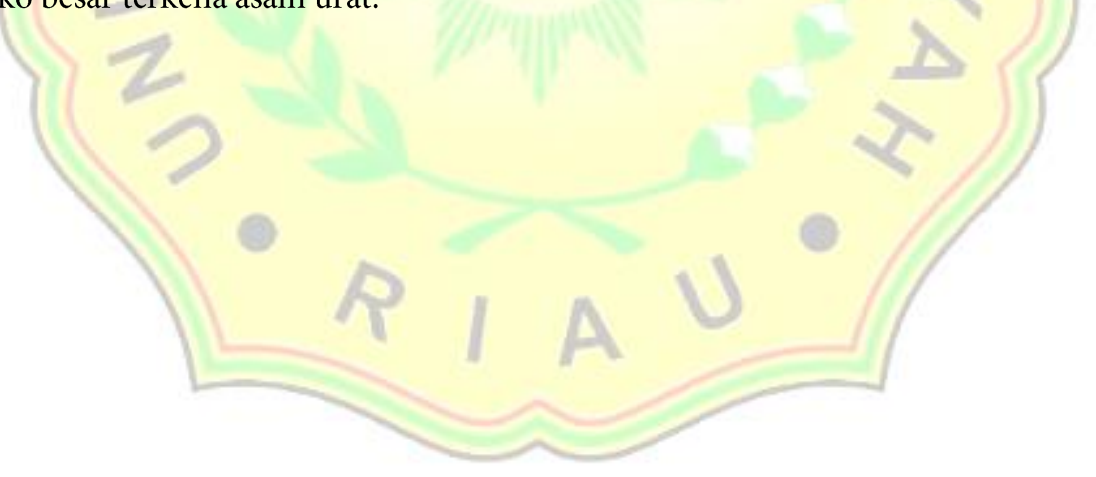


Tabel 4.2

Distribusi Frekuensi Pretest Kompres Ekstrak Jahe Terhadap Nyeri Sendi Pada Lansia Dengan Arthritis Gout di Panti Sosial Tresna Werda Khusnul Khatimah Pekanbaru Riau

\begin{tabular}{lcc}
\hline \multicolumn{1}{c}{ Pretest } & Frekuensi & Presantase \\
\hline a. Nyeri Ringan & 1 & $5 \%$ \\
\hline b. Nyeri Sedang & 1 & $5 \%$ \\
\hline c. Nyeri Berat & 34 & $90,0 \%$ \\
\hline Jumlah & 36 & $100 \%$ \\
\hline
\end{tabular}

Berdasarkan tabel 4.2 didapatkan bahwa hasil pretest di penelitian ini yang mayoritas adalah nyeri berat yaitu sebanyak 34 orang responden $(90,0 \%)$

Tabel 4.3

Distribusi Frekuensi Posttest Kompres Ekstrak Jahe Terhadap Nyeri Sendi Pada Lansia Dengan Arthritis Gout di Panti Sosial Tresna Werda Khusnul Khatimah Pekanbaru Riau

\begin{tabular}{ccc}
\hline Post test & Frekuensi & Presantase \\
\hline a. Nyeri Ringan & 5 & $14,0 \%$ \\
\hline b. Nyeri Sedang & 25 & $69,4 \%$ \\
\hline c. Nyeri Berat & 6 & $17,0 \%$ \\
\hline Jumlah & 36 & $100,0 \%$ \\
\hline
\end{tabular}

Berdasarkan tabel 4.3 didapatkan bahwa Postest di penelitian ini yang mayoritas adalah Nyeri sedang yaitu sebanyak 25 orang responden $(69,4 \%)$

\section{Analisa Bivariat}

Analisa bivariat digunakan untuk melihat nyeri sendi pada kelompok eksperimen dan melihat efektifitas pre dan post kompres ekstrak jahe terhadap nyeri sendi pada lansia. Hasil penelitian ini dikatakan efektif apabila nilai $p$ value $<0,05$. Hasil uji Paired $t$ test dimana $p$ value kompres ekstrak jahe $=0,000$ lebih kecil dari nilai alpha $(p<0,05)$ didapatkan adanya pengaruh kompres ekstrak jahe yang signifikan antara pre dan post kompres ekstrak jahe.

Data analisa menyimpulkan ada pengaruh kompres ekstrak jahe terhadap nyeri sendi pada lansia. Hal ini sejalan dengan penelitian yang dilakukan (Siti Dina, 2015) bahwa ada kompres ekstrak jahe terhadap penurunan nyeri sendi pada lansia setelah diberikan intervensi dengan melakukan kompres ekstrak jahe dengan $p$ value $=0,000$. Hal ini menunjukkan bahawa Ho ditolak dan $\mathrm{Ha}$ diterima. Dengan demikian ada pengarun penurunan nyeri sendi sebelum dan sesudah dilakukan kompres ekstrak jahe pada lansial. Hal ini disebabkan kompres ekstrak jahe memilikikandungan gingerol yang mengandung siklooksigenase yang bisa menghambat terbentuknya prostaglandin sebagai mediator nyeri, sehingga terjadi penurunan nyeri sendi (Hadi, 2014).

Hal ini sejalan dengan hasil penelitiaan oleh (Siti Dina, 2015) bahwa terdapat pengaruh konpres air rendaman jahe terhadap penurunan nyeri sendi pada lanjut usia pada seluruh lansia yang mengalami asam urat sebanyak 30 orang dengan menggunakan uji $t$ Test didapatkan $p$-value $=0,000$ $(<0,01)$.

Menurut (Aspiani, 2014) mengatakan adapun Pengobatan non farmakologis seperti mengompres bagian sendi kecil. Jahe adalah obat yang menjadi pilihan utama untuk menurunkan Nyeri Sendi Pada Lansia Dengan Asam Urat (Artritis Gout) karena selain tidak memiliki efek samping bagi kesehatan, obat ini juga mudah dikonsumsi, mudah terjangkau dalam hal segi ekonomi, dan juga tidak berat untuk dikonsumsi (Syafrifatul, 2014). Pengobatan non farmakologis bagi pasien asam urat darah pada dasarnya adalah dengan menjada makanan, mengontrol berat badan, 
perubahan gaya hidup, olahraga yang cukup, minum air putih secukupnya. Masyarakat menggunakan pengobatan alternatif untuk mengatasi berbagai penyakit (Ari \& Liana, 2016).

Berdasarkan teori lokasi persendian yang terkena terutama sendi-sendi kecil yaitu sendi jari tangan dan jari kaki. Bila kristal urat tertimbun pada jaringan diluar sendi maka akan membentuk atau topus yaitu benjolan bening dibawah kulit yang berisi kristal urat, kristal urat ini juga dapat menyebabkan timbulnya batu asam urat (Handryani,2011).

Hal ini sejalan dengan hasil penelitiaan oleh (Syarifatul, 2014) bahwa terdapat efektifitas kompres rebusan jahe terhadap penurunan nyeri sendi pada lansia di unit Rehabilitas Sosial Wening Wardoyo Ungaran pada seluruh lansia yang mengalami asam urat sebanyak 66 orang dengan menggunakan uji Wilcoxon Sign Rank Test didapatkan $p$-value $=0,000(<0,05)$.

Hasil uji Paired $t$ test $p$ value $=0.000$ lebih kecil dari nilai alpha $(<0.05)$, dengan hasil ini berarti $\mathrm{H0}$ ditolak. Hal ini menunjukkan bahwa adanya efektifitas yang signifikan rata-rata frekuensi nyeri sendi sesudah melakukan kompres ekstrak jahe pada kelompok. Penelitian ini dapat disimpulkan bahwa kompres ekstrak jahe berpengaruh pada lansia yang menderita nyeri sendi dengan asam urat.

Pemberian kompres ekstrak jahe dapat menurunkan nyeri sendi, karena jahe dapat meningkatkan kemampuan kontrol terhadap nyeri, Jahe memiliki rasa pedas dan bersifat hangat. Bebrapa bahan dalam jahe diantaranya gingerol, limonene,a-linolenic acid, aspartic, b-sitossterol, tepung kanji, caprilyc acid, capsaicin, chlorogenic acid, dan parsenol. Efek farmakologis yang dimiliki jahe, merangsang ereksi penghambat keluarnya enzim 5-lifooksigenase dan siklooksigenase serta meningkatkan aktivitas kelenjar endokrin (Heryana, 2009). Menurut (Puspaningtyas \&Utami, 2013) jahe sering kali digunakan sebagai obat nyeri sendi karena kandungan ginerol dan rasa hangat yang ditimbulkannya membuat pembuluh darah terbuka dan memperlancar sirkulasi darah. Suplai makanan dan oksigen menjadi lebih baik sehingga nyeri sendi akan berkurang (Syafrifatul, 2014)

\section{KESIMPULAN}

Diketahui bawah jumlah responden yang berjenis kelamin Laki-Laki yaitu 9 responden (25,0\%) dan responden berjenis kelamin Perempuan yaitu 27 responden (75,0\%). Sedangkan diketahui bahwa jumlah responden yang berusia elderly (60-74 tahun) yaitu 25 responden $(69,4 \%)$ dan responden yang berusia Old (7590 tahun) yaitu 11 responden (30,6\%).

Hasil uji paired t test dimana $p$ value $=0.000$ lebih kecil daripada nilai alpha $(p<0,05)$ didapatkan adanya perbedaan yang signifikan antara mean efektifitas nyeri sendi sebelum dan sesudah melakukan kompres ekstrak jahe pada kelompok eksperimen pemberian kompres ekstrak jahe terhadap nyeri sendi pada lansia. Penelitian ini diharapkan kepada Panti Sosial Tresna Werdha Khusnul Khotimah untuk memberikan penyuluhan terhadap efektifitas kompres ekstrak jahe terhadap nyeri sendi.

\section{UCAPAN TERIMAKASIH}

Terima kasih ditujukan kepada pimpinan STIKes Pekanbaru Medical Center pekanbaru dan Panti Sosial Tresna Werdha Khusnul Khotimah Pekanbaru yang telah memberikan bantuan secara moril dan finansial dalam penyusunan penelitian ini hingga selesai.

\section{DAFTAR PUSTAKA}

Ari \& Liana, 2016. Perawatan Lansia Penderita Nyeri Sendi Dalam Keluarga dan Masyarakat. pekanbaru:UR

Badan Pusat Statistik, 2012. Statistik Penduduk Usia Lanjut Usia. jakarta: BPS

Badan Penelitian Dan Pengembangan Kesehatan Republik Indonesia, 2013. Riset Kesehatan Dasar 2013. Jakarta:

Kementrian Kesehatan Republik Indonesia. diakses melalui www.depkes.go.id

Black Joyce M, 2014. Keperawatan Medikal Bedah. Elsevier, Jakarta

Brunner \& suddart, 2010 Keperawatan Medikal Bedah. EBC, Jakarta

Departemen kesehatan RI, 2013 dalam buku ari \& liana, 2016. Perawatan Lansia Penderita Nyeri Sendi Dalam Keluarga Dan Masyarakat. pekanbaru: UR 
Heriana 2009 dalam jurnal syafrifatul, 2014. Jurnal Perbedaan Efektifitas Pemberian Kompres Air Hangat Dan Pemberian Kompres Air Jahe Terhadap Penurunan Nyeri Sendi Pada Lansia Di Unit Rehabilitas Sosial Wening Wardoyo Ungaran. Jakarta

Handryani didalam jurnal siti dina, 2015. jurnal kompres air rendaman Jahe Dapat Menurunkan Nyeri Pada Lansia Dengan Asam Urat Didesa Cengkalsewu Kecamatan Sukolilo Kabupaten Pati. yogyakarta. diakses melalui http://jurnal.stikescendekiautamakudus.ac.id/

Izza Syafrifatul, 2014. Jurnal Perbedaan Efektifitas Pemberian Kompres Air Hangan Dan Pemberian Kompres Air Jahe Terhadap Penurunan Nyeri Sendi Pada Lansia Di Unit Rehabilitas Sosial Wening Wardoyo Ungaran. Jakarta

koizer \& Erb 2009 dalam jurnal syafrifatul, 2014. Jurnal Perbedaan Efektifitas Pemberian Kompres Air Hangan Dan Pemberian Kompres Air Jahe Terhadap Penurunan Nyeri Sendi Pada Lansia Di Unit Rehabilitas Sosial Wening Wardoyo Ungaran. Jakarta

Masyhurroyidi Hadi, 2014. Jurnal Pengaruh Kompres Rebusan Air Jahe Terhadap Tingkat Nyeri Sebakut Dan Kronis Pada Lanjut Usia Dengan Asam Urat Di Puskermas Arjuna Kecamatan Klojen Malang Jawa Timur. Jawa timur, Majalah kesehatan FKUB

Muhith Abdul \& Siyoto Sandu, 2016. Pendidikan Keperawatan Gerontik, andi Yogyakarta

Ma'rifat, 2011. Keperawatan Gerontik. jakarta. ERB

Notoadmojo, 2012. Metodelogi Penelitian Kesehatan. Rineka Cipta, Jakarta

Nursalam, 2014. Metodelogi Penelitian Ilmu Keperawatan. Salemba Medika, Jakarta

Notoadmojo, 2012. Metodelogi Penelitian Kesehatan. Rineka Cipta, Jakarta

Rizki Nugraheni 2011 dalam syafrizal, 2014 Jurnal Perbedaan Efektifitas Pemberian Kompres Air Hangan Dan Pemberian Kompres Air Jahe Terhadap Penurunan Nyeri Sendi Pada Lansia Di Unit Rehabilitas Sosial Wening Wardoyo Ungaran. Jakarta

Riskesdes, 2013. Badan Penelitian Dan Pengembangan Kesehatan Kementrian Kesehatan RI. jakarta

Syafrifatul, 2014. Jurnal Perbedaan Efektifitas Pemberian Kompres Air Hangan Dan Pemberian Kompres Air Jahe Terhadap Penurunan Nyeri Sendi Pada Lansia Di Unit Rehabilitas Sosial Wening Wardoyo Ungaran. Jakarta

Tim lentera didalam jurnal siti dina, 2015. jurnal kompres air rendaman Jahe Dapat Menurunkan Nyeri Pada Lansia Dengan Asam Urat Didesa Cengkalsewu Kecamatan Sukolilo Kabupaten Pati. Yogyakarta.ndiakses melalui http://jurnal.stikescendekiautamakudus.ac.id/

Utami \& puspaningtyas dalam jurnal syafrifatul, 2014. Jurnal Perbedaan Efektifitas Pemberian Kompres Air Hangan Dan Pemberian Kompres Air Jahe Terhadap Penurunan Nyeri Sendi Pada Lansia Di Unit Rehabilitas Sosial Wening Wardoyo Ungaran. Jakarta

Yudiyanta, 2015.Assement Nyeri. yogyakarta. CDK 